Gribrán Cruz-Martinez, Melissa Fernández Arrigoitia, Janialy Ortiz Camacho \& Patricia Román-Velazquez

\title{
The Making of Caribbean Not-so-Natural Disasters
}

Alternautas is a peer reviewed academic journal that publishes content related to Latin American Critical Development Thinking.

It intends to serve as a platform for testing, circulating, and debating new ideas and reflections on these topics, expanding beyond the geographical, cultural and linguistic boundaries of Latin America - Abya Yala. We hope to contribute to connecting ideas, and to provide a space for intellectual exchange and discussion for a nascent academic community of scholars, devoted to counterbalancing mainstream understandings of development.

How to cite:

Cruz-Martinez G., Fernández M., Ortiz J., \& Román-Velazquez P. (2018), The Making of Caribbean Not-so-Natural Disasters. Alternautas, 5(2), 4-12. URL : http://www.alternautas.net/blog/2018/9/7/introduction-to-the-special-issue-themaking-of-caribbean-not-so-natural-disasters

Editor : Alternautas

http://www.alternautas.net

London, UK.

ISSN - 2057-4924 
Introduction $\mid 4$

\section{Introduction to the Special Issue: 'The Making of Caribbean Not-so-Natural Disasters' ${ }^{2}$}

Hurricanes are not a novelty in the Caribbean. However, 2017 left several shocking facts for history books regarding intensity and frequency. Two Category 4 and two Category 5 hurricanes - the strongest category on the Saffir-Simpson scale - hit the Caribbean in a month's-time. For the first time since 1899, the northern Leewards Caribbean Islands (i.e., islands starting to the East of Puerto Rico, with Dominica being the southernmost of the group) experienced three major hurricanes in three weeks: Irma, Jose and Maria (Astor, 2017). A tropical storm or a hurricane made landfall in Bahamas, Barbuda, Cuba, Puerto Rico, Saint Martin, Trinidad, Virgin Gorda, and the Yucatan peninsula. The 2017 hurricane season was also the costliest (US $\$ 320$ billion in damages), the ninth-most active (17 storms of which 10 were hurricanes), and with ten consecutive hurricane storms - the highest number since reliable records began in 1851 (Belles, 2017; McAdams et al., 2017).

\footnotetext{
' GIBRAN CRUZ-MARTINEZ is a Juan de la Cierva Researcher at the Institute of Public Goods and Policies, CSIC (Spain). MELISSA FERNÁNDEZ ARRIGOITIA is a Lecturer in Urban Futures, Sociology Department, Lancaster University (United Kingdom). JANIALY ORTIZ CAMACHO is a Socio-Cultural Anthropologist with Higher Education Studies and Ethnographic Experience in Puerto Rico, Canada and Spain. PATRIA ROMAN is a Senior Lecturer in Media \& Creative Industries at Loughborough University (United Kingdom).

${ }^{2}$ This article was originally published in http://www.alternautas.net/blog/2018/9/7/introductionto-the-special-issue-the-making-of-caribbean-not-so-natural-disasters on September 7th, 2018.
} 
Hurricane María hit Puerto Rico as a category four storm (sustained winds of $155 \mathrm{mph}$ ), leaving the archipelago in a state of emergency. Essential services such as power, potable water and communication services collapsed (Duany, 2017). On Wednesday 20 September the lives of Puerto Ricans on the archipelago and abroad changed forever. The first response from the Puerto Rico and United States federal government was insufficient and slow (Sosa Pascual \& Mazzei, 2017). Flooding did not discriminate between marginalised and affluent neighbourhoods. However, like the damage caused by Katrina in New Orleans (Werner 2017; Brand 2018), the archipelago's natural disaster uncovered the soaring levels of inequality, unequal status and commodification of disaster-related recovery for Puerto Rican residents. To varying degrees, this 'Not-So-Natural Disaster' (Lloréns et al. 2018; Seda-Irizarry and Martínez-Otero 2017) has also affected ravished Caribbean neighbours like Bermuda, the British Virgin Islands and Dominica - with their own variable 'sovereign' political arrangements and spatial and socio-economic frontiers of unequal development.

Colonialism and human-induced factors are behind the high levels of inequality, climate change and incomplete recoveries in the Caribbean region, which increase the region's vulnerability to disaster (Gahman \& Thongs, 2017). The Caribbean faces tremendous risks from hurricanes due to its geographical location; however research shows how socioeconomic conditions (i.e. poverty levels and social inequality) "play a role in explaining the intensity and consequences of such phenomena. Thus, no event is strictly or exclusively natural." (López-Calva \& Ortiz Juárez, 2008, pp. 1). Policy legacies of western powers' occupations still have effects on the islands' governance (Danticat, 2015). For example, Caribbeans on income poverty tend to live in disaster-prone areas. They are exposed to landslides and floods during the hurricane and see their chances reduced of receiving relief after the disaster due to accessibility limitations of relief-efforts brigades. The responses to this and other natural disasters are generally linked to colonial histories and powers that still dominate the psyche and geopolitical relationships of the region. This is evident in the response that both France and Britain had over Hurricane Irma only a couple of weeks before Maria made landfall. The 2017 hurricane season evidence the crucial 
role played by grassroots organisations and organised communities providing relief efforts due to the limited or lack of government response.

The government of Puerto Rico recently stated that "the devastation caused by Hurricanes Irma and Maria creates an opportunity to redesign" the role of the government and the market (AAFAF, 2018:11). The Caribbean government is following Prince's (1920) centenary idea of portraying a disaster as a chance of permanent social change, without addressing the deep and enduring imperial conditions of colonial capitalism and exploitation (masked as savioursim) that have been wreaking havoc on the archipelago's social, financial, environmental and infrastructural systems. Jones (2009: 318) argues that major disasters "have rarely sparked significant social changes, other than to solidify the power base of elites and further immiserate the poor". This reproduction of inequality can be seen in the wake of hurricane Maria, through the attack on an already weakened and financially beleaguered public infrastructure, including its public energy and education system- a tactic Naomi Klein $(2007,2018)$ has critically framed as disaster capitalism and 'the shock doctrine' in cases like post-Katrina New Orleans, post-tsunami Sri Lanka, and more recently in Puerto Rico. Referred to also as a 'doctrine of trauma' (Bonilla 2015), a unique exploitation of distress, buttressed by a selective visual economy of abandonment that heralds US intervention as indispensable (Lebrón and Arbona 2018) appears to be underway in the archipelago; where long-standing crises-political, economic and environmental-- are being used to justify further acts of negligence and austerity. Given that the future Puerto Rico envisioned in the revised fiscal plan proposes further austerity measures, privatisations, stagnation, liberalisation and flexibilization of the labour market (AAFAF, 2018), we must ask ourselves, what type of significant social change would these post-disaster policies bring to residents? Moreover, how are alternative, citizen-led initiatives dynamically responding to these long terms and emergent scenarios?

Beyond Puerto Rico, what kind of alternative Caribbean futures are being imagined and enacted in the wake of the 2017 hurricane season, and how are these entangled with a sense of greater infrastructural, relief or racial justice-- both local and regional? This special issue addresses the disaster conditions, responses and consequences not 
only in Puerto Rico but also in the impacted neighbouring islands of Barbuda, Dominica and Cuba. We expect this to be the beginning of a number of critical social research examining the Dominica, Haïti, Turks \& Caicos, Virgin Islands, Montserrat, Guadeloupe, St Kitts \& Nevis, St. Martin the Dominican Republic, and the rest of Caribbean countries who encounters natural and not-so-natural disasters. We open this special issue with an article by Javier A. Arce-Nazario. Javier explores the narratives and experiences of communities without access to the public water system in post-Hurricane María. He collected data between September 2017 and January 2018 through telephone and face-to-face interviews using a combination of structured and open-ended questions. Javier argues that the residents' narratives highlight hidden instruments of agency needed to gain access to water in the aftermath of a natural disaster. These elements go beyond having access to objects, incorporating expertise, cooperation and experience with previous crises. The paper presents narratives that counter official assessments of water use and water systems, showing that people appreciate water for reasons beyond chemical water quality. Community managed groundwater (e.g. wells), and surface water systems (e.g. streams and springs) have demonstrated to be alternative water sources for rural communities without access to the large public water system. Javier ends his essay by arguing that for effective disaster relief, policymakers need to listen more frequently and carefully to Puerto Rico's people, landscapes and history.

The second article by Oscar Webber uncovers the role played by the plantation agriculture in enhancing hurricane vulnerability in the British Caribbean. He argues that historians are suited to examine the historical roots of individuals' vulnerability which are made evident after nature-induced hazards although they are constructed over time. Comparing the 1831 hurricane in Barbados and the 1834 hurricane in Dominica, Oscar exposes the role played by plantations in the aggravation of hurricane vulnerability. The article shows that the more expansive plantation agriculture of Barbados exposed its inhabitants to far greater human, economic and environmental losses than in Dominica. For example, deforestation had serious implications for the cohesion of the Barbadian soils, causing landslides and serious threats to Barbados' inhabitants. While the plantation did not increase the risk of 
epiphenomenal hazards in both Caribbean islands, the marginalisation of space and energy directed towards growing subsistence crops prolonged the recovery process and the starvation caused by the natural disasters. Oscar concludes with a reflection and a proposal to further research on the acceptable limits to development and the priorities of governments in the Caribbean.

The third article by César J. Pérez-Lizasuain argues that Puerto Rico's historic territorial-colonial status and the 'degenerative evolution' of this core political arrangement - alongside the introduction of neoliberal rationalities - created the postMaria environment we are witnessing now, where highly mediatised individual neoliberal subjects of resilience are held responsible for overcoming what are, in fact, long-term structural vulnerabilities. This stands in stark contrast to the alternative self-led community initiatives and forms of sociability (autogestión comunitaria) that have been emerging throughout the archipelago and which the author frames as an emancipatory politics of radical autonomy, characterised by multiple sovereignties, which challenges the country's dominant neoliberal, colonial context.

In the fourth article, Robert Coates takes Hurricane Irma as a case study to argue that Cuba's relief efforts and strategies to mitigate risk and limit damage deserve attention beyond political polemics. In a provocative article, Coates seeks to recast theories of Cuban exceptionalism to understand strategies of resilience by the Cuban government and people, and thus he offers key insights into Caribbean disasters and vulnerability as a whole. He invites the reader to think about the lessons that could be extracted from a series of successful strategies based around preparedness and trust. Coates argues that trust networks in the context of hazard exposure work best when political resolve and societal trust and resilience nurture each other.

The fifth article by Lily Bui discusses the disagreements and challenges concerning Puerto Rico's rewiring process after Hurricane Maria, now that the country's government has announced its intentions to have PREPA, the public power utility, privatised. In trying to find solutions that go beyond the public-private dichotomy, the author explores the conditions under which Puerto Rico is currently contemplating the alternatives for building a 'sustainable' energy regime. It 
accurately introduces these aspects as narratives employed in an economic and political context, and subsequently, the tensions amongst competing forces to spearhead energy transformation. The author notices how renewable energy alternatives are predominately proposed by community-based initiatives, local scientists, and other groups at the grassroots level. However, the lack of democratic capacity and political support, have stopped efforts to materialise these initiatives. For Bui, it is indispensable to develop a clear vision of the archipelago's energy future, one that can be negotiated, designed and implemented by as many stakeholders as possible.

In the sixth article, Fernando Tormos contextualises the Puerto Rican Left in relation to the archipelago's political economy, identifies the forces in the Puerto Rican Left, reviews their differences and recent history, and presents a brief analysis of their political influence in Puerto Rican and US politics. Fernando argues that Hurricane Maria exacerbated the ongoing fiscal and humanitarian crisis, but also made evident the role played by the Puerto Rican left, socialists, environmentalists and youth activists groups in the reconstruction and relief process. Moreover, he argues that while left-wing parties have not been effective in the electoral game, grassroots organisations and left-wing forces are building power from below - in the streets and the traditionally marginalised communities. The article also highlights how the hurricane opened the door for the actual government to privatise public corporations and the education system, and to implement a set of neoliberal policies (e.g., labour reforms). Fernando concludes with a reflection on the path forward of the left in the aftermath of Hurricane Maria.

Sarah Molinari reviews in the seventh essay the latest book by Naomi Klein entitled 'The Battle for Paradise. Puerto Rico takes on the Disaster Capitalists'. Sarah argues that Puerto Rico is facing an unprecedented conjuncture of an ongoing selective austerity regime and large-scale hurricane recovery. This review discusses Naomi Klein's The Battle for Paradise (2018) and how in the wake of a social disaster, different groups struggle over opposing visions for Puerto Rico's future. Klein builds on her "shock doctrine" analysis to discuss Puerto Rico's layered "doses" of shock politics as rooted in the trauma Puerto Ricans experienced pre-Maria throughout the 
economic crisis. Using vivid case examples of existing alternatives to disaster capitalism throughout the archipelago, Klein gestures to what a "just recovery" might look-like.

Finally, the special issue ends up with a Poem by Celeste Ramos, a London-based writer of fiction, poetry, short film and essays from New York City. In her poem 'the danger of sighing while looking up', Celeste narrates her personal experience of suffering before and after the Caribbean was being devastated by Hurricane Maria. The emotions described in the poem resemble those felt by a large part of the Caribbean diaspora: lack of news from family members in the islands, the repetition of news on Youtube, and the unanswered messages in social media. Celeste equates 'watching' with feeling guilty; waiting for news and watching the news.

The pieces in this special issue evidence the making of not-so-natural disasters in the Caribbean and propose alternative scenarios for resilient recovery. Alternative community organisations and grassroots movements demonstrated to be complementary actors to the limited and slow state- of market-relief response. The historical prioritization of Caribbean government towards perpetual economic growth in their development agendas, evidence the marginalization of space in the region. A space that could be used to grow subsistence crops, which is not only essential to mitigate starvation after a natural disaster but reduces the dependency on food imports. The hurricanes also demonstrated to be an opportunity for implementing neoliberal policies that previous governments were not able to be put in place due to internal resistance from interest groups or the general population. The Caribbean will continue to be a hurricane-receiving area because of its geographical situation, but as these articles argue, political, economic and social reforms can reduce the human suffering caused by the natural and not-so-natural disasters.

\section{References}

AAFAF (2018) New Fiscal Plan for Puerto Rico (Draft Submission). Puerto Rico Fiscal Agency and Financial Advisory Authority, February 12, 2018, retrieved from http://www.aafaf.pr.gov/assets/newfiscalplanforpr-02-12-2018.pdf 
Astor, M. (2017) 'The 2017 Hurricane Season Really Is More Intense Than Normal', The New York Times, 11/19/2017, retrieved from: https://www.nytimes.com/2017/09/19/us/hurricanes-irma-harvey-maria.html

Belles, J. (2017) '2017 Atlantic Hurricane Season Recap: 17 Moments We'll Never Forget', The Weather Channel, 28/11/2017, retrieved from https://weather.com/storms/hurricane/news/2017-11-11-moments-hurricane-seasonatlantic-irma-maria-harvey

Bonilla, Y. (2015) Non-Sovereign Futures: French Caribbean Politics in the Wake of Disenchantment, University of Chicago Press.

Brand, A.L. (2018) 'The duality of space: The built world of Du Bois' double-consciousness', Environment and Planning D: Society and Space, 36(1): 3-22.

Danticat, E. (2015) The Long Legacy of Occupation in Haiti. The New Yorker, July 28, retrieved from: https://www.newyorker.com/news/news-desk/haiti-us-occupationhundred-year-anniversary

Duany, J. (2017) Ten key facts about Puerto Rico after Hurricane Maria. Oxford University Press's Academic Insights for the Thinking World. Retrieved from https://blog.oup.com/2017/12/ten-facts-about-puerto-rico-after-hurricane-maria/

Gahman, L. and Thongs, G. (2017) 'In the Caribbean, colonialism and inequality means hurricanes hit harder', The Conversation, September 20, retrieved from: https://theconversation.com/in-the-caribbean-colonialism-and-inequality-meanhurricanes-hit-harder-84106

Jones, M.M. (2009) There is no such thing as a natural disaster: Race, class, and hurricane Katrina, Global Public Health, 4:3, 318-320, DOI: 10.1080/17441690902831253

Klein, N. (2007) The Shock Doctrine: The Rise of Disaster Capitalism, Penguin.

Klein, N. (2018) The Battle for Paradise. Puerto Rico takes on the Disaster Capitalists. Chicago: Haymarket Books.

Lebrón, M. and Arbona, J. (2018) Resisting Debt and Colonial Disaster in Post-Maria Puerto RIco, The Funambulist: Politics of Space and Bodies, 16 (March-April).

López-Calva, L.F. and Ortiz Juárez, E. (2008) Evidence and Policy Lessons on the Link between Disaster Risk and Poverty in Latin America: Summary of Regional Studies. 
Research for Public Policy, RPP LAC - MDGs and Poverty - 10/2008, UNDP.

Prince, S.H. (1920) Catastrophe and social change. New York: Columbia University.

Lloréns, H., Santiago, R., Garcia-Quijano, C.G. and de Onís, C.M. (2018) Hurricane Maria: Puerto Rico's Unnatural Disaster, Social Justice: a journal of crime, conflict and world order, January 22 2018, retrieved from_http://www.socialjusticejournal.org/hurricanemaria-puerto-ricos-unnatural-disaster/

McAdams, R., H. Lewis and T. Gonzalez (2017) '2017 Hurricane Season Recap and 2018 Implications for Utilities'. ScottMadden Management Consultants, 1/12/2017, retrieved from:_https://www.scottmadden.com/insight/2017-hurricane-season-recap2018-implications-utilities/

Seda-Irizarry, I. and Martínez-Otero, H. (2017) 'Puerto Rico's Not-So-Natural Disaster', Jacobin, October 24 2017, retrieved from_https://jacobinmag.com/2017/10/puertorico-natural-disaster-hurricane-maria

Sosa Pascual, O. \& P. Mazzei (2017) Huracán María: dónde falló el operativo de respuesta. Centro de Periodismo Investigativo / Miami Herald, 22 de Octubre 2017, retrieved from__ http://periodismoinvestigativo.com/2017/10/huracan-maria-donde-fallo-eloperativo-de-respuesta/

Werner, M. (2017) “'We are citizens!” Puerto Rico and the Caribbean from Hurricane Katrina to Maria', Society and Space, retrieved from http://societyandspace.org/2017/10/06/we-are-citizens-puerto-rico-and-thecaribbean-from-hurricane-katrina-to-maria/\# 